\title{
Posterior Temporal Artery
}

National Cancer Institute

\section{Source}

National Cancer Institute. Posterior Temporal Artery. NCI Thesaurus. Code C33384.

An artery arising from the insular section of the middle cerebral artery that supplies the posterior temporal lobe. 